\title{
In situ detection of methylated DNA by histo endonuclease-linked detection of methylated DNA sites: a new principle of analysis of DNA methylation
}

Takehiko Koji • Shiho Kondo • Yoshitaka Hishikawa •

Shucai An · Yoko Sato

Published online: 5 December 2008

(C) Springer-Verlag 2008

Erratum to: Histochem Cell Biol (2008) 130:917-925

DOI 10.1007/s00418-008-0487-7

The concentration of the Tris/HCl buffer (page 919, line 14)

should be $25 \mathrm{mM}$ and not $825 \mathrm{mM}$.

The online version of the original article can be found under doi:10.1007/s00418-008-0487-7.

T. Koji $(\square) \cdot$ S. Kondo $\cdot$ Y. Hishikawa $\cdot$ S. An $\cdot$ Y. Sato

Department of Histology and Cell Biology,

Nagasaki University Graduate School of Biomedical Sciences,

1-12-4 Sakamoto, Nagasaki 852-8523, Japan

e-mail: tkoji@nagasaki-u.ac.jp 